Hadi Zarghani ${ }^{1}$, Sajad Mijani ${ }^{*}{ }^{1}$, Samieh Eskandari Nasrabadi ${ }^{2}$, Mohhamad Ghias-Abadi ${ }^{1}$, Surur Khorramdel ${ }^{1}$, Reyhaneh Azimi ${ }^{1}$

${ }^{1}$ Agronomy Department, Faculty of Agriculture, Ferdowsi University of Mashhad, , Mashhad, Iran ${ }^{2}$ School of environment and rural science, University of New England, Armidale, Australia;

*sajad.mijani@stu.um.ac.ir;

\title{
TEMPERATURE EFFECTS ON THE SEED GERMINATION OF SOME PERENNIAL AND ANNUAL SPECIES OF ASTERACEAE FAMILY
}

\begin{abstract}
Temperature is the most critical factor determining success or failure of plant establishment. Seed germination response of five medicinal species include three seed-propagated perennial species, Cichorium intybus, cynara scolymus and Echinacea purpurea and vegetative-reproduction perennial species, Achillea millefolium and annual species, Matricaria aurea were assessed at constant temperatures. The seeds were exposed to constant temperatures of $5,10,15,20,25,30,35,40$ and $45^{\circ} \mathrm{C}$ under total darkness. Germination percentage of all the species were significantly affected by various temperatures $(\mathrm{p} \leq 0.001)$. A. millefolium did not germinate at $5-10$ and $35-45^{\circ} \mathrm{C}$, but showed noticeable germination percentage $(73.3-100 \%)$ at temperatures ranged from $15-30^{\circ} \mathrm{C}$. The highest total germination percentage was observed within the range of $15-35^{\circ} \mathrm{C}$ for other species. Also, we calculated cardinal temperatures (the minimum, optimum and maximum temperature) for seed germination of species. The highest value for minimum temperature was $10.07^{\circ} \mathrm{C}$ in $\mathrm{A}$. millefolium followed by $C$. scolymus and $M$. aurea $\left(5^{\circ} \mathrm{C}\right)$ while the lowest was for E. purpurea and C. intybus $(2.68$ and $2.90^{\circ} \mathrm{C}$ respectively). The lowest value for optimum temperature was detected in $\mathrm{A}$. millefolium $\left(22.72^{\circ} \mathrm{C}\right)$ and $M$. aurea $\left(23.88^{\circ} \mathrm{C}\right)$ while the maximum values were observed in $E$. purpurea and C. intybus $\left(30.40^{\circ} \mathrm{C}\right.$ and $29.90^{\circ} \mathrm{C}$ respectively). Based on results of present study we concluded that species with both vegetative and seed-propagated reproduction forms like A. millefolium had smaller temperature range rather those with just one way of reproduction (seed production).
\end{abstract}

Key words: cardinal temperatures, dark germination, life cycle, medicinal species

Communicated by Ryszard Górecki 


\section{INTRODUCTION}

Germination can be considered as the most fundamental event in successful growing of annual crops leading crop production (Khajeh-Hosseini et al., 2003; Soltani et al., 2006). Germination as a complex physiological process and one of the most crucial stages in seedling establishment which has great significance in ultimate density of the crop is affected by different environmental factors such as temperature, light, oxygen and moisture; hence, knowing more about germination behavior in domestication procedure particularly for wild species with unknown germination requirements is inevitable (Kharkwal et al., 2002). Temperature affects the onset, potential and rate of germination (Roberts, 1988; Flores and Briones, 2001), and is thereby always the most critical factor determining success or failure of plant establishment (Kader and Jutzi, 2004). Each plant species in different phases of its life cycle, and in a given series of circumstances, has a base temperature $\left(\mathrm{T}_{\mathrm{b}}\right)$ below which it will not grow, an optimum temperature (or range of temperatures) $\left(\mathrm{T}_{\mathrm{opt}}\right)$ at which it grows well, and as a final point maximum temperature $\left(\mathrm{T}_{\max }\right)$ above which growth will be stopped entirely (Jami Al-Ahmadi and Kafi, 2007). In general, different seeds can germinate whenever environmental conditions for growth and development of seedlings are guaranteed and totally cardinal temperature of a particular seed depends on environmental conditions in which it is adapted (Alvarado and Bradford, 2002).

In cultivation and domestication of medicinal plants, being informed about the germination procedure is an essential key in order to reach successful crop establishment (Runham, 1998). Usually, the effectiveness of vegetative reproduction in perennial herbaceous species is high compared with sexual (seed) reproduction. Nevertheless, Reproduction by seeds is largely important to starting growth in new habitats (Heimann and Cussans, 1996). The primary objective of this study was to survey seed germination response of medicinal species include annual species (Matricaria aurea (Loefl.) Schultz-Bip.), seed-propagated perennial species (Cichorium intybus L. ,cynara scolymus L. and Echinacea purpurea L.( and vegetativereproduction perennial species (Achillea millefolium L. (to different temperatures and determine the cardinal temperatures for their germination. 


\section{MATERIALS AND METHODS}

\section{Source of seeds}

Seeds of five medicinal plant species used in study were collected in 2011 from the herbal garden of medicinal plants, Research Station of Faculty of Agriculture, Ferdowsi university of Mashhad located in central part of the Khorasan Razavi province, Iran. Names and different characteristics of these species are mentioned in Table1. No fertilizer was used during plant growth and they were irrigated.

Table 1

List of some characteristics of medicinal plant species related to Asteraceae family

\begin{tabular}{llll}
\hline \multicolumn{1}{c}{ Species } & \multicolumn{1}{c}{ Life cycle } & \multicolumn{1}{c}{ Proliferation } & \multicolumn{1}{c}{ Life history } \\
\hline Achillea millefolium L. & Perennial & Seed \& Rhizome & Summer \\
Cichorium intybus L. & Perennial & Seed & Summer \\
Cynara scolymus L. & Annual \&Perennial† & Seed \& Rhizome & Fall/Winter \\
Echinacea purpurea L. & Perennial & Seed & spring \\
Matricaria aurea (Loefl.) Schultz-Bip. & Annual & Seed & spring \\
\hline
\end{tabular}

$\dagger$ C. scolymus L. is traditionally cultivated, as a perennial crop However, new development in cultivars of seeded artichoke has allowed them to be grown as an annual (Vilchez et al., 2005). So, The primary method for its reproduction is by seed

\section{Germination test}

Because of reported innate dormancy for species of Asteraceae family (Baskin et al., 1992; Baskin et al., 1995; Van Auken, 2001; cruz-mazo et al., 2010) after one year of storing in dark condition with temperature around $25^{\circ} \mathrm{C}$, mature and intact seeds were selected for germination test. First of all sodium hypochlorite $(\mathrm{NaOCl}) 1 \%$ was used to sterilize surfaces of the mature seeds for 5 minutes and then seeds were thoroughly rinsed with pure water. For each experiment, 25 seeds were placed on doublelayered Whatman no. 1 filter paper in Petri dishes and moistened with deionized water. The Petri dishes were sealed with Parafilm to prevent the seeds from drying out and small amounts of water were added as needed. The response to temperature was evaluated over the range $5-45^{\circ} \mathrm{C}$, at $5^{\circ} \mathrm{C}$ intervals using dark germinators with $60-70 \%$ relative humidity for 14 days. Germinated seedlings were counted and removed every 24 hours. A seed was considered as germinated when its radicle protruded through the seed coat at least $5 \mathrm{~mm}$. Counting finished when no seed germinated during 4 consecutive days. 


\section{Statistical analysis}

Before statistical analysis, a normality test was performed for all data of germination percent and data was transformed $(\arcsin ) \sqrt{x / 100}$ when required. Data was subjected to analysis of variance (ANOVA). For each species at different temperatures, the data was analyzed as a completely randomized design with four replications. Bonferroni's adjustment was used for mean comparisons with $\alpha=0.05$.

\section{Modeling}

Cumulative germination percentage was plotted against time (Day) and time (D) to $50 \%$ of germination was determined by fitting a logistic model to cumulative germination percentage $(G)$ against time $(D)$ as below (Kamkar et al., 2012):

$$
G=\frac{G_{x}}{1+e^{a \times(t-b)}}
$$

where; $G_{x}$ is the maximum germination percentage, b is the time for $50 \%$ germination and $a$ is a parameter. Germination rate, calculated as the inverse of time to reach $50 \%$ germination $\left(D_{50}\right)$

As there are different kinds of statistical models to determine the cardinal temperatures (Yan and Hunt, 1999), three models including Segmented model (Soltani et al., 2006) (Equation2), parabolic regression (Shafii and Price, 2001) (Equation3) and Five-parameter beta model (Yin et al., 1995) (Equation4) were used in order to modeling and accurate determination of cardinal temperatures for each species. Adjusted $\mathrm{R}^{2}$ was used as a statistical index to settle the best model, which fits properly to each species. Models fitted by using the nonlinear regression procedure of Sigma Plot 11.

$$
\begin{array}{ll}
f=a_{1}+b_{1} \times T & \left(T<T_{\text {opt }}\right) \\
f=a_{2}+b_{2} \times T & \left(T>T_{\text {opt }}\right)
\end{array}
$$

There are four parameters in the bilinear approach, $a_{1}, b_{1}, a_{2}$ and $b_{2}$, from which the three cardinal temperatures can be derived.

$$
1=t_{50}=a^{\circ}+b \times t e m p+c \times t e m p 2+e_{i} \ldots
$$

where; $a, b$ and $c$ are the intercept, first, and second-order coefficients, respectively, and $e_{i}$ is error term under standard linear regression assumptions. While the estimated value for $T_{o}$ was calculated by differentiation, those for $T_{b}$ and $T_{m}$ Were obtained by extrapolation to the intercept with the abscissa.

$$
\begin{gathered}
f=e^{\mu \times\left(T-T_{b}\right)^{\alpha}} \times\left(T_{m}-T\right)^{\beta} \\
T_{0}=\frac{\alpha \times T_{m}+\beta \times T_{b}}{(\alpha+\beta)}
\end{gathered}
$$


where; $T, T_{b}, T_{o}$, and $T_{m}$ are temperature, base, ceiling, optimum and maximum temperatures respectively. In addition, $\mu, \alpha$, and $\beta$ are model parameters. The parameters $\alpha$ and $\beta$ determine the curvatures of the relationship for the temperature range between $T b$ and $T_{o}$ and between $T_{o}$ and $\mathrm{T}_{\mathrm{m}}$, respectively.

Difference of maximum and minimum temperature for germination known as Temperature Range (TR) (Equation 5) show the germination ecological range of species.

$$
T R=T_{m}-T_{b}
$$

where; $\mathrm{T}_{\mathrm{m}}$ and $\mathrm{T}_{\mathrm{b}}$ indicate temperatures above and below which germination will be stopped.

RESULTS

Germination percentage

Table 2

Temperature effects on seed germination percentage of some medicinal plants of Asteraceae family

\begin{tabular}{llcccccccc}
\hline \multirow{2}{*}{ Species } & \multicolumn{10}{c}{ Temperature $\left[{ }^{\circ} \mathrm{C}\right]$} \\
\cline { 2 - 10 } & 5 & 10 & 15 & 20 & 25 & 30 & 35 & 40 & 45 \\
\hline A. millefolium & $-\dagger$ & $0.0^{\mathrm{D}}$ & $73.3^{\mathrm{C}}$ & $89.3^{\mathrm{B}}$ & $100.0^{\mathrm{A}}$ & $76.0^{\mathrm{C}}$ & $0.0^{\mathrm{D}}$ & - & - \\
C. intybus & $0.0 \mathrm{E}$ & $18.0^{\mathrm{D}}$ & $32.0^{\mathrm{C}}$ & $50.6^{\mathrm{B}}$ & $78.6^{\mathrm{A}}$ & $85.3^{\mathrm{A}}$ & $58.6^{\mathrm{B}}$ & $24.0^{\mathrm{CD}}$ & $0.0^{\mathrm{E}}$ \\
c. scolymus & $0.0^{\mathrm{C}}$ & $70.6^{\mathrm{B}}$ & $88.0^{\mathrm{A}}$ & $96.0^{\mathrm{A}}$ & $97.3^{\mathrm{A}}$ & $97.3^{\mathrm{A}}$ & $96.0^{\mathrm{A}}$ & $0.0^{\mathrm{C}}$ & - \\
E. purpurea & $0.0^{\mathrm{D}}$ & $30.6^{\mathrm{C}}$ & $52.0^{\mathrm{BC}}$ & $73.3^{\mathrm{AB}}$ & $90.6^{\mathrm{A}}$ & $90.6^{\mathrm{A}}$ & $77.3^{\mathrm{AB}}$ & $26.6^{\mathrm{CD}}$ & $0.0^{\mathrm{D}}$ \\
M. aurea & $0.0^{\mathrm{C}}$ & $56.0^{\mathrm{B}}$ & $69.3^{\mathrm{AB}}$ & $86.6^{\mathrm{A}}$ & $86.6^{\mathrm{A}}$ & $78.3^{\mathrm{A}}$ & $70.0^{\mathrm{AB}}$ & $0.0^{\mathrm{c}}$ & - \\
\hline
\end{tabular}

Any two means not sharing a letter within row differ significantly $(P<0.01) . \dagger$ : Dash for each temperature indicates that was not analyzed by ANOVA and mean comparison

The result showed that germination percentage of all the species were significantly affected by various temperatures $(\mathrm{p} \leq 0.001)$ (Table 2$)$. The highest total germination percentage was observed within the range of 15$35^{\circ} \mathrm{C}$, while the lowest germination percentage was detected at 10 and $40^{\circ} \mathrm{C}$ (Tabe 1). In each level of temperatures from $10-35^{\circ} \mathrm{C}$, maximum germination percentage was observed for c.scolymus (70.6-97.3\%) and there was just an exception for A. millefolium at $25^{\circ} \mathrm{C}$, reached the peak of $100 \%$. None of the species germinated at $5^{\circ} \mathrm{C}$ and $45^{\circ} \mathrm{C}$. Despite the fact that A. millefolium did not germinate at $5-10$ and $35-45^{\circ} \mathrm{C}$, this species showed noticeable germination percentage $(73.3 \%-100 \%)$ at temperatures ranged from $15-30^{\circ} \mathrm{C}$. At $40^{\circ} \mathrm{C}$, the germination of E. purpurea and $C$. intybus reached $26.6 \%$ and $24 \%$, respectively. Some of the species showed signifi- 
cant reduction in germination by $5^{\circ} \mathrm{C}$ enhancement in temperature. Surprisingly, there was no sign of germination for C. scolymus and M. aurea at $40^{\circ} \mathrm{C}$, while at $35^{\circ} \mathrm{C}$; they reached $96 \%$ and $70 \%$ of germination, respectively. Moreover, A. millefolium followed the same pattern at 30 and $35^{\circ} \mathrm{C}(76 \%-0$ respectively).

\section{Modeling}

For each species, cardinal temperatures (base or minimum temperature, optimum and ceiling or maximum temperature) were estimated by fitting three regression equations including Five-parameter beta, segmented and quadratic polynomial models (Fig. 1). However, the best model defined based on the highest adjusted $\mathrm{R}^{2}$ of regression equations for each species (Table 3). Quadratic model provided an accurate prediction of germination response of $A$. millefolium to temperature across all study models $\left(\mathrm{R}^{2}=0.96\right)$. As mentioned, this species had no germination at fewer than 15 and above $30^{\circ} \mathrm{C}$. Since there was lack of data compared with other species in graphs, quadratic polynomial model can be considered as the best model for cardinal temperature estimation of those, which have fewer data. The segmented model represented the best fit for C. intybus and E. purpurea while Five-parameter beta model recognized as the most proper model for C. scolymus and M. aurea.

Calculated cardinal temperatures $\left({ }^{\circ} \mathrm{C}\right)$ of medicinal plants of Asteraceae family based on models of germination rate-temperature

\begin{tabular}{|c|c|c|c|c|c|c|}
\hline Species & $\begin{array}{c}\text { T base } \\
\left(T_{b}\right)\end{array}$ & $\begin{array}{c}\text { Toptimum } \\
\left(\mathrm{T}_{\mathrm{o}}\right)\end{array}$ & $\begin{array}{c}\text { T maximum } \\
\left(T_{m}\right)\end{array}$ & Adj $R^{2}$ & Model & $\begin{array}{c}\text { Temperature } \\
\text { Range }\left(\mathrm{T}_{\mathrm{m}}-\mathrm{T}_{\mathrm{b}}\right)\end{array}$ \\
\hline A. millefolium & 10.07 & 22.72 & 35.12 & 0.96 & $\begin{array}{c}\text { Quadratic Poly- } \\
\text { nomial }\end{array}$ & 25.05 \\
\hline C. intybus & 2.90 & 29.90 & 46.26 & 0.90 & Segmented & 39.36 \\
\hline C. scolymus & 5.00 & 26.09 & 40.33 & 0.92 & Beta & 35.33 \\
\hline E. purpurea & 2.68 & 30.40 & 45.85 & 0.88 & Segmented & 43.17 \\
\hline M. aurea & 5.00 & 23.88 & 40.05 & 0.94 & Beta & 35.05 \\
\hline
\end{tabular}

Adj $\mathrm{R}^{2}$ represent adjusted $\mathrm{R}^{2}$

\section{Germination rate and Cardinal temperatures of germination}

Fig. 1 shows the germination rate $\left(1 / t_{50}\right)$ response to temperature. By increasing temperature beyond 25 and $30^{\circ} \mathrm{C}$, the germination rate of all species was decreased and this reduction was far more noticeable in A. millefolium and C. scolymus because at super-optimal temperatures germination rate of these species reached the lowest amount. At $25^{\circ} \mathrm{C}$, the highest germi- 
nation rate was specialized to A. millefolium and C. scolymus while at $30^{\circ} \mathrm{C}$, $C$. intybus, E. purpurea and $M$. aurea had maximum rate. There was a significant difference between the temperature at which the highest germination rate was obtained and other temperatures in all the species except $M$. aurea in which there was no significant difference between $15-25^{\circ} \mathrm{C}$ (data not shown).
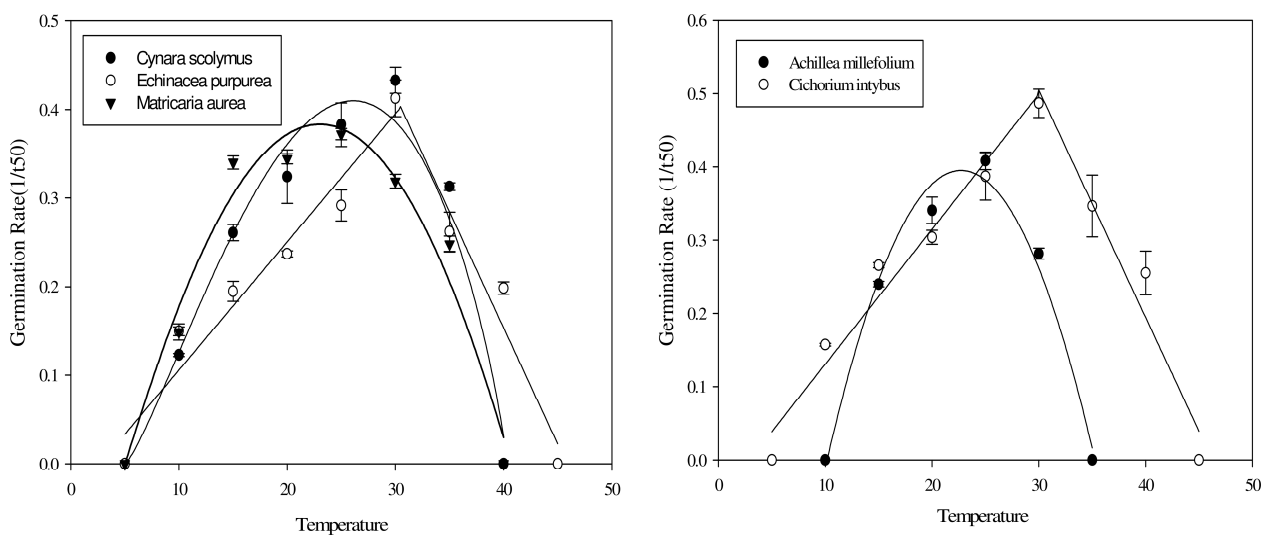

Fig. 1 Germination rate $\left(1 / t_{50}\right)$ of medicinal species of Asteraceae family to temperature. Segmented fitted model (E. purpurea) and Beta fitted model (C. scolymus and M. aurea) (left).Segmented fitted model (C. intybus) and Quadratic Polynomial fitted model (A. millefolium) (right)

The comparison of perennial and annual species germination rates represented in Fig. 1 and 2 has been specified that C. intybus has greater germination rate in compared with other species which is much more evident at high temperatures. A. millefolium had higher rate of germination than other species at 20 and $25^{\circ} \mathrm{C}$. At $15^{\circ} \mathrm{C}$, M. aurea as an annual species stood at the first place of germination rate while at $20^{\circ} \mathrm{C}$ could not exceed than A. millefolium. After $20^{\circ} \mathrm{C}$ there was a reduction in germination rate of M. aurea. (Fig. 1). By increasing the temperature up to $30^{\circ} \mathrm{C}$ the germination rate of E. pupurea And C. scolymus enhanced and since then the germination rate decreased. Germination rate decline after $30^{\circ} \mathrm{C}$ in C. scolymus was far more considerable and at $40^{\circ} \mathrm{C}$, it reached the lowest amount (zero) while the germination activity of E. pupurea ceased at $45^{\circ} \mathrm{C}$. Totally $C$. intybus as a seed-propagated perennial medicinal species had superior germination rate rather than other vegetative-reproduction perennial and annual species. All the estimated cardinal temperatures are provided in Table 3. The results indicated that the highest value for $\mathrm{T}_{\mathrm{b}}$ is $10.07^{\circ} \mathrm{C}$ in $\mathrm{A}$. millefolium followed by C. scolymus and $M$. aurea $\left(5^{\circ} \mathrm{C}\right)$ while the lowest values was observed in E. pupurea and C. intybus (2.68 and $2.90^{\circ} \mathrm{C}$ respectively). $\mathrm{T}_{\mathrm{o}}$ is a temperature or range of temperature at which germination rate is high and more seed germinate during less time. The lowest value for optimum temperature was detected in A. millefolium $\left(22.72^{\circ} \mathrm{C}\right) . \mathrm{T}_{\mathrm{o}}$ in $M$. aurea 
was $23.88^{\circ} \mathrm{C}$ while the maximum values for $\mathrm{T}_{\mathrm{o}}$ were observed in $E$. purpurea and C. intybus $\left(30.40^{\circ} \mathrm{C}\right.$ and $29.90^{\circ} \mathrm{C}$ respectively). Ceiling or maximum temperature $\left(\mathrm{T}_{\mathrm{m}}\right)$ at which the germination stops was defined $40^{\circ} \mathrm{C}$ or above for almost all the species except $A$. millefolium in which germination stopped at about $35^{\circ} \mathrm{C}$.

Temperature range factor showing the temperate gap between start and end of the germination is obtained from $T_{b}$ and $T_{m}$ difference in the other word that is a range of temperatures within which seeds can germinate (Table 3). In this experiment E. purpurea and C. intybus (with $43^{\circ} \mathrm{C}$ and $39^{\circ} \mathrm{C}$ respectively) had the largest temperature range of germination. The lowest value was $25^{\circ} \mathrm{C}$ in $\mathrm{A}$. millefolium.

DISCUSSION

\section{Germination percentage}

In the present study, low (less than $10^{\circ} \mathrm{C}$ ) and high (more than $40^{\circ} \mathrm{C}$ ) temperatures results in low germination for all species (Table 1). Seed germination reduction at low temperatures is highly related to germination rate decrease, whereas at high temperatures is associated to high endogenous Abscisic acid contents that inhibit germination (Toyomasu et al., 1993). Among species, despite of low temperature range A. millefolium shows high germination percentage. So that, it can be concluded that this temperature range reduction for germination will be compensated by high germination activities. Germination of E. purpurea and C. intybus at $40^{\circ} \mathrm{C}$ show their adaptation to tropical regions.

As mentioned above none of tested species germinated at $5^{\circ} \mathrm{C}$, possibly it is because of the time period considered 14 days in this study. Generally, since germination rate declines at low temperatures, period between sowing date and emergence will increase (Berti and Johnson, 2008). Obviously, seeds of $A$. millefolium as a perennial species with vegetative reproduction respond differently to temperature than seeds of $C$. intybus, C. scolymus and E. purpurea as seed-propagated perennial species and $M$. aurea as annual species. This means that, A. millefolium did not germinate at both high and low temperatures and had lower temperature range for germination than others. Probably, species with both vegetative and seed-propagated reproduction forms can acclimatize much more efficiently rather those with just one way of reproduction.

The effect of temperature range $\left(5\right.$ to $\left.45^{\circ} \mathrm{C}\right)$ on several seed lots of $A r$ temisia vulgaris L. (Asteraceae family) as a perennial weed that regenerate usually by Rhizome system and occasionally produce viable seeds was investigated by Önen (2006); results showed that the maximum seed germina- 
tion percentages were obtained over the range of 15 to $30{ }^{\circ} \mathrm{C}$. According to results of Önen's investigation, three seed lots did not germinate at 5 and $45{ }^{\circ} \mathrm{C}$. Furthermore, results of $\mathrm{Wu}$ et al. (2007) on Flaxleaf fleabane (Conyza bonariensis L. Cronquist) (an annual or short-lived perennial plant) indicated that there was no germination activity at 5 and $35^{\circ} \mathrm{C}$ for mentioned species. Muoghalu \& Chuba (2005) conducted a survey on seed germination of Tithonia diversifolia as a perennial plant reproducing both sexually and asexually and Tithonia rotundifolia as an annual plant reproducing only sexually. They proved that the seeds of these species had a period of dormancy before germination. Their results showed that germination percentage of $T$. diversifolia and $T$. rotundifolia after approximately four or six months, were 45 and 97.5 per cent respectively. Thus, therefore, a perennial species show better germinability than an annual species.

As mentioned before in present study seeds were tested after one year of storing in dark condition. dry storage at low to medium temperatures for 26 months can stimulate seeds to germinate (Van Auken, 2001). Additionally, results of Cruz-mazo et al. (2010) signified that the natural dormancy of Achenes of the three scorzoneroides species (Asteraceae) after dispersal diminished after six months in dry storage, and practically disappeared after a year in storage.

Germination rate and Cardinal temperatures of germination

Alvarado and Bradford (2002) found that with increasing temperature up to optimum level, rate of germination was increased and declined thereafter. Such a trend was observed for all species in this study. After $25^{\circ} \mathrm{C}$ there was a reduction in germination rate of $M$. aurea. and A. millefolium So that, mild weather is more appropriate for they. For E. pupurea, C. intybus And C. scolymus this reduction was after $30^{\circ} \mathrm{C}$, Therefore, we can conclude that soil and weather warmth is fine for their germination.

According to the results and this fact that $\mathrm{T}_{\mathrm{b}}$ is the temperature at which germination start, late planting will be beneficial for A. millefolium while will have negative effects on other species germination and probably their growth. On the other hand, $T_{b}$ indicates competitive advantage between the weeds and main crops in germination stage, so each species that germinate sooner uses the supplies earlier and will be successful in competition with weeds. The minimum temperature for A. millefolium seed germination resembles warm-season crops, such as corn or sorghum (Woltz and Tekrony, 2000) thus; planting date should delay until the soil temperature reaches $10^{\circ} \mathrm{C}$. Base temperature of other species is similar to spring species. Nadjafi et al. (2009) showed that base temperatures of eleven plant species were within the range of $0-4^{\circ} \mathrm{C}$. Their results specified that Centaurea benedicta belonging to Asteraceae had the lowest value for base temperature 
$\left(0^{\circ} \mathrm{C}\right)$. An understandable comprehension of the seed germination responses is valuable in screening tolerance of crops and cultivars to low or high temperatures and in identifying geographical areas where a species or genotype can germinate and establish successfully by using the cardinal temperatures (Kamkar et al., 2012).

The lowest optimum temperature was in A. millefolium $\left(22.72^{\circ} \mathrm{C}\right)$; it seems that temperate weather makes this species germinate steadily. The maximum optimum temperatures were observed in E. purpurea and $C$. intybus. By the results, we can conclude that a uniform germination will happen in hot temperatures. On the other hand, it can be concluded that Perennial plants reproduce by seeds had higher optimal temperatures than annual and vegetative-propagated reproduction perennial species. But, Hall et al. (2012) believed that the optimal temperature for the germination of Diplotaxis spp. does not seem to be influenced by the perennial or annual nature of the plants. In another experiment, $\mathrm{T}_{\mathrm{o}}$ for seed germination of $C$. intybus reported same our results. Corbineau and Côme (1990) reported seeds of Endive (Cichorium intybus L.) germinate in a broad range of temperatures $\left(5^{\circ}\right.$ to $30^{\circ} \mathrm{C}$ ), but the thermal optimum was between $25^{\circ}-30^{\circ} \mathrm{C}$. C. scolymus performed like a spring species by reaching the maximum germination rate at $26.09^{\circ} \mathrm{C}$. This result is Inconsistent with the results of Ierna et al. (2004). The base, optimal and maximum temperature for seed germination of globe artichoke $\left(C\right.$. scolymus) calculated 4,16 and $32.5^{\circ} \mathrm{C}$, respectively. $\mathrm{T}_{\mathrm{b}}$ for this species represents germination like winter crop. On the other hands, Welbaum and Steven (1992) stated the globe artichoke is cannot be successfully grown as a perennial in areas where winter temperatures are consistently below $-10^{\circ} \mathrm{C}$. Only the temperature base was close to our findings while $T_{o}$ and $T_{m}$ were different to our result. Differences were possibly because of environmental differences of growing conditions of the seed and or genetic differences (Önen, 2006). On the other hand, species from a wide range of plant families, life cycle types, and plant communities exhibited the differences in germination characteristics of seeds collected from different locations (Baskin and Baskin, 1998). The optimum temperature for means of all seed lots of A. vulgaris L. as a perennial weed was $29^{\circ} \mathrm{C}$ (Önen, 2006). According to Heimann and Cussans (1996), seeds of Cirsium arvensis (perennial species) germinate best at relatively high temperatures $\left(25-30^{\circ} \mathrm{C}\right)$. Optimum temperatures were found to be about $22^{\circ} \mathrm{C}$ for two flax (Linum usitatissimum L.) cultivar seeds (an annual species reproducing by means of seed) (Orhan, 2012). 


\section{CONCLUSIONS}

Results show that $C$. intybus as a seed-propagated perennial species has high germination rate in different temperatures than annual and vegetativereproduction perennial species. Here, we proposed an indicator in name of Temperature range factor that showing range of temperatures within which seeds can germinate. It is important to mention that annual species (M. aurea) and perennial species (C. intybus, C. scolymus and E. purpurea,) which propagate just by their seeds have bigger temperature range compared with perennial species such as A. millefolium that reproduces by both seeds and vegetative organs (Rhizomes). Based on results of present study we concluded that probably, species with both vegetative and seedpropagated reproduction forms like A. millefolium invest less for production of stronger seed rather those with just one way of reproduction. Because, perennial species are reliance more on vegetative reproduction organs for their survival. All of species show lower $T_{b}$ for their germination like the spring varieties, except $A$. millefolium. Hence, early sowing will be better for them by the way field experiments will be required.

\section{ACKNOWLEDGEMENTS}

I wish to thank Dr. M. Nassiri Mohalati for their technical assistance.

\section{REFERENCES}

Alvarado V., Bradford K.J. 2002. A hydrothermal time model explains the cardinal temperature for seed germination. Plant Cell and Environment 25: 1061- 1069.

Auld D.L., Bettis B.L., Crock J.E., Kephart D. 1988. Planting date and temperature effects on germination, emergence and seed yield of chickpea. Agronomy Journal 80: 909-914.

Auken van O.W. 2001. Germination requirements of seeds of Helianthus paradoxus (Asteraceae). Texas Journal of Science 53: 157-70.

Baskin C.C., Baskin J.M., Auken van O.W. 1992. Germination response patterns to temperature during after ripening of achenes of four Texas winter annual Asteraceae. Canadian Journal of Botany-Revue Canadienne De Botanique 70: 2354-2358.

Baskin C.C., Baskin J.M., Auken van O.W. 1995. Temperature requirements for dormancy break and germination in achenes of the winter annual Lindheimera texana (Asteraceae). Southwest Naturalist 40: 268272 .

Baskin C.C., Baskin J.M. 1998. Seeds: ecology, biogeography, and evolution of dormancy and germination. Academic Press, London.

Berti M.T., Johnson B.L. 2008. Seed germination response of cuphea to temperature. Industrial Crops and Products 27: 17-21.

Corbineau F., Côme D. 1990. Germinability and quality of Cichorium intybus L. seeds. Acta Horticulturae 267: $183-190$.

Cruz-Mazo G., Narbona E., Buide M. 2010. Germination patterns of dimorphic achenes in three related species of scorzoneroides (Asteraceae, Lactucaceae) growing in different environments. Annales Botanici Fennici 47: 337-345.

Dobos J., Bernath J. 1985. Germination-biological investigations with papaver-somniferum poppy varieties of different origin and growth cycle. Herba Hungarica 24: 35-48. 
Flores J., Briones O. 2001. Plant life-form and germination in a Mexican intertropical desert: effects of soil water potential and temperature. Journal of Arid Environments 47: 485-497.

Hall M.K.D, JoblingJ.J., Rogers G.S. 2012. The germination of perennial wall rocket (Diplotaxis tenuifolia (L.) DC.) and annual garden rocket (Eruca sativaMill.) under controlled temperatures. Plant breeding and seed science 65:15-28

Heimann B., Cussans G.W. 1996. The importance of seeds and sexual reproduction in the population biology of Cirsium arvense - a literature review. Weed Research 36: 493-503.

Ierna A., Restuccia A., Mauromicale G. 2004. Effects of seed osmpriming on germination of Cynara cardunculus under low, optimal and high temperatures. Acta Horticulturae 660: 333-338.

Jami Al-Ahmadi M., Kafi M. 2007. Cardinal temperature for germination of Kochia scoparia (L.). Journal of Arid Environments 68: 308-314.

Kader M.A, Jutzi S.C. 2004. Effects of thermal and salt treatments during imbibitions on germination and seedling growth of sorghum at 42/19 ${ }^{\circ} \mathrm{C}$. Journal of Agronomy Crop Science 190: 35-38.

Kamkar B., Jami Al-Alahmadi M., Mahdavi Damghani A., Villalobosd F.J. 2012. Quantification of the cardinal temperatures and thermal time requirement of opium poppy (Papaver somniferum L.) seeds to germinate using non-linear regression models. Industrial Crops and Products 35: 192-198.

Khajeh Hosseini M., Powell A.A., Bingham I.I. 2003. The interaction between salinity stress and seed vigor during germination of soybean seeds. Seed Science and Technology 31: 715-725.

Kharkwal A.C., Prakash O.M., Bhattacharya A., Nagar P.K., Ahuja P.S.. 2002. Method for inducing improved seed germination in Podophyllum hexandrum Royle. United States Patent Number 6, 449, 899.

Muoghalu J.I., Chuba D.K. 2005. Seed germination and reproductive strategies of Tithonia diversifolia (hemsl.) Gray and Tithonia rotundifolia (PM) Blake. Applied Ecology and Environmental Research 3: $39-46$.

Nadjafi F., Tabrizi L., Shabahang J., Mahdavi Damghani A.M. 2009. Cardinal germination temperature of some medicinal plant species. Seed Technology 31(2):156-163

Orhan, K. 2012. A predictive model for the effects of temperature on the germination period of flax seeds (Linum usitatissimum L.). Turkish Journal of Agriculture and Forestry 36: 654-658

Önen, H. 2006. The influence of temperature and light on seed germination of mugwort (Artemisia vulgaris L.). Journal of Plant Diseases and Protection 393-399.

Runham, S. 1998. Small scale study of yield and quality of oils from six herb species. MAFF project Nf0505.pp.30.

Shafii B., Price W.J. 2001. Estimation of cardinal temperatures in germination data analysis. Journal of Agricultural, Biological, and Environmental Statistics 6(3): 356-366.

Soltani A., Robertson M.J., Trabi B., Yousefi M., Sarparast R. 2006. Modeling seedling emergence in chickpea as affected by temperature and sowing depth. Agricultural and Forest Meteorology 138: 156-167.

Toyomasu T., Tsuji H., Yamane H., Nakayama M., Yamaguchi I., Murofushi N., Takahashi N., Inoue Y. 1993. Light effects on endogenous levels of gibberellins in photoblastic lettuce seeds. Journal of Plant Growth Regulation 12: 85-90.

Vilchez M., Paulus A.O., Mayberry K.S. 2005. Globe artichoke seed treatment to control seed borne fungi and seed quality evaluation. Acta Horticulturae 681: 581-586.

Welbaum G.E., and C.S. Warfield. 1992. Growing globe artichokes from seed. Acta Horticulturae 318: 111116.

Wiese A.M., Binning L.K. 1987. Calculating the threshold temperature of development for weeds. Weed Science 35:177-179.

Woltz J.M., Tekrony D.M. 2000. Accelerated aging test for corn seed. Seed Technology 23: 21-34.

Wu, H., Walker S., Rollin M.J., Tan D.K.Y., Robinson G., Werth J. 2007. Germination, persistence and emergence of flaxleaf fleabane. Weed biology and Management 7: 192-9.

Yan W., and L.A. Hunt .1999. An equation for modelling the temperature response of plants using only the cardinal temperatures. Annals of Botany 84: 607-614.

Yin X., Kropff M.J., McLaren G., Visperas R.M. 1995. A nonlinear model for crop development as a function of temperature. Agricultural and Forest Meteorology 77: 1-16. 